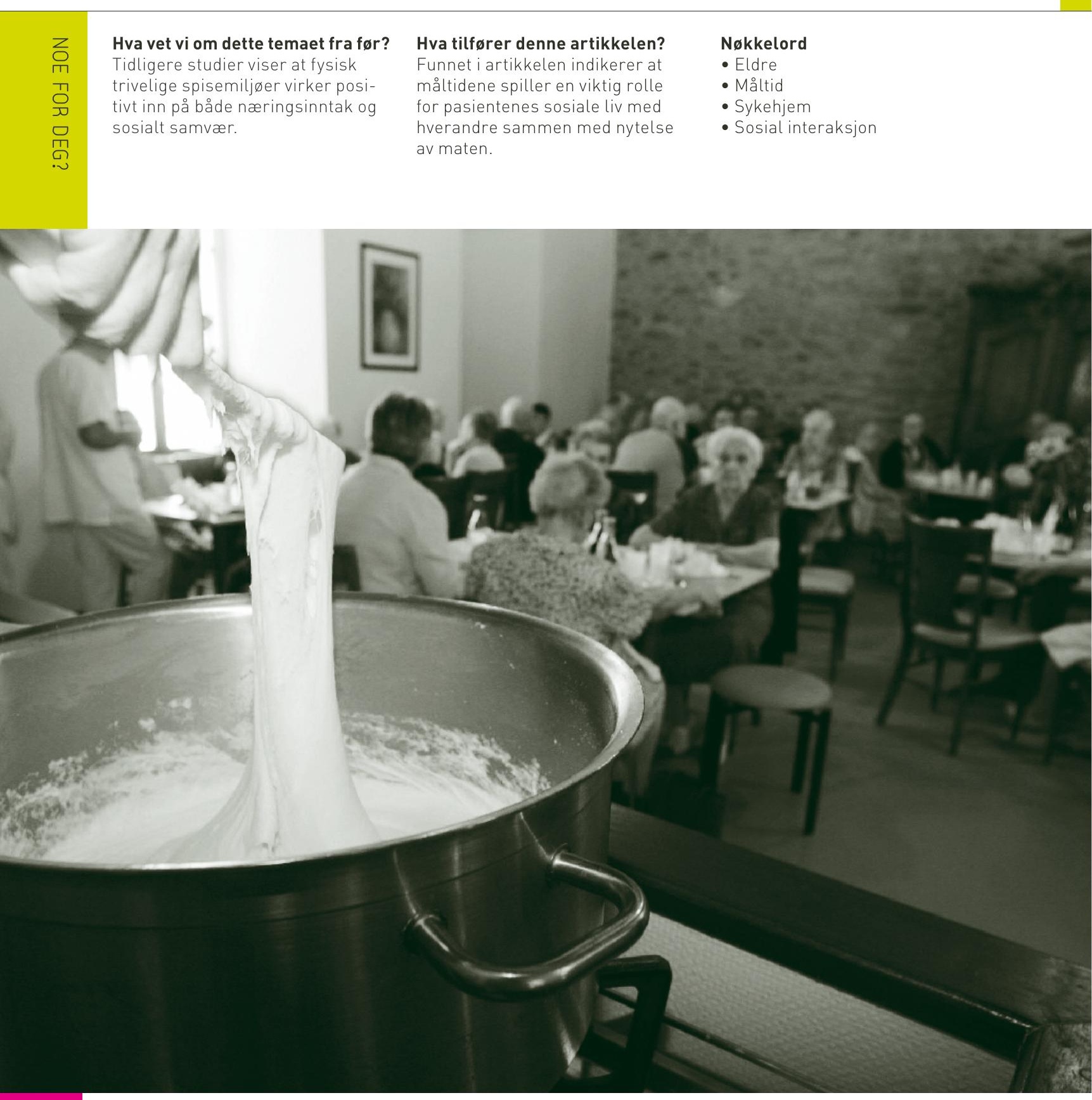

Hensikten med denne artikkelen er å beskrive eldre pasienters erfaringer med måltidene i sykehjem. For å kunne forbedre sykepleiepraksis er det viktig å ha kunnskap om måltidenes muligheter for sosial interaksjon. Kvalitativt forskningsintervju ble anvendt som metode, der syv eldre pasienter mellom 82-96 år ble intervjuet. Data ble analysert slik Kvale skisserer en kvalitativ innholdsanalyse. Funnene indikerer at måltidene spiller en viktig rolle for pasientenes sosiale liv med hverandre sammen med matens nytelse. Måltidene ble for pasientene en kilde for velvære alene eller i samvær med andre, selv med reduserte kommunika- sjonsevner og begrenset sosial interaksjon. Pasientene roste personalets bidrag til samtale, selv om de som regel var travelt opptatt med å servere. Måltidet gav dem en mulighet til å sitte sammen med noen på tross av mangelen på konversasjonspartnere. Få foretrakk å spise alene på eget rom. 


\section{Om forfatteren}

Bente Gunn Melheim, Sykepleier, cand.san og høyskolelektor i sykepleie.
Avdeling for helsefag,

Høgskolen i Sogn og Fjordane

E-postadresse:

bente.gunn.melheimahisf.no
Dobbeltpublisering

Artikkelen er tidligere publisert i

Klinisk Sygepleje; 21:2,26-34.

\section{»Pasientopplevelser av måltidsfellesskap i sykehjem}

\author{
Tekst: Bente Gunn Melheim \\ Illustrasjonsfoto: Colourbox.com
}

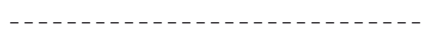

Artikkelens hensikt er å formidle hvordan det kan oppleves for pasienter å være delaktige i et institusjonalisert måltidsfellesskap i sykehjem. Hvilke forhold pasientene vektlegger som sentrale, vil kunne få konsekvenser for organisering og utøvelse av sykepleie i ulike måltidssituasjoner. Et måltid i sykehjem foregår i en sosial kontekst noe forskjellig fra hva de fleste vil ha erfaring med fra tidligere. Pasienter vil i ulik grad være avhengige av hjelp til å ivareta egne behov. Det vises ikke bare i hvordan eller hvor mye man spiser, men også i hvordan man deltar i det sosiale fellesskapet rundt maten. Pasientenes opplevelser fokuseres gjennom personlige intervjuer for å gi innblikk og forståelse for måltidsfellesskapet. Artikkelen bygger på min hovedfagsstudie med temaet eldre pasienters opplevelser av måltid i ett sykehjem (1).

Et måltid rommer noe av det mest sentrale i et menneskes liv. Teologen Brunstad ser måltidet som en kilde og en opprettholdelse av fellesskapet vi mennesker er avhengige av. Måltidet skal være et rytmisk og rituelt avbrekk i hverdagen, hvor man blir sett, hørt og lyttet til. Maten deles i fellesskap med andre. Måltidet gir næring og øvelse i sosial kompetanse, der bordskikk legger grunnlaget for samhandling med andre mennesker. Måltidsfellesskapet forsterker identitet og selvaktelse ved at vi gir hverandre anerkjennelse. Ved å bli husket på av andre, innlemmes man i fellesskapet. Når man spiser sammen, blir man synlige for hverandre. Et anerkjennende blikk fastholder det forpliktende i relasjonen. Blir man derimot oversett, blir man usynlig for den andre (2).

I sykepleielitteraturen er måltidet sentralt plassert i sykepleier, hovedsaklig sett fra en ernæringsmessig synsvinkel, men også ut fra den miljømessige tilretteleggingen. Florence Nightingale gir råd om hvordan man på best mulig måte kan fremme et godt miljø rundt måltidet (3). I Rikke Nissens lærebok vektlegges viktigheten av rommets beskaffenhet som et godt sted å være når man spiser (4). Virgi- nia Henderson ser det å hjelpe pasienten med mat og drikke som ett av flere gjøremål, der sykepleierne har et spesielt ansvar for å opprettholde et helsefremmende miljø rundt pasienten, "pleasent environment» $(5,6)$. Karniala på sin side hevder at flere lærebøker i sykepleie hovedsakelig presenterer spising som en fysiologisk prosess og et fysiologisk behov, fremfor å trekke veksler på de psykologiske, sosiologiske og kulturelle dimensjonene ved spisingen (7).

Også mye av tidligere forskning rundt dette fenomenet er fra et ernæringsmessig perspektiv, men flere av studiene har fått frem ulike aspekter knyttet til miljø og fellesskap ved måltider (8-14). Disse studiene viser at det kan være avgjørende om man spiser sammen med mennesker man trives sammen med (8-10), eller om man opplever atmosfæren rundt måltidet som god (8). Personalets tilstedeværelse kan være avgjørende for en positiv og trygg opplevelse $(11,15)$. Fysisk trivelige spisemiljøer har tidligere vist seg å virke positivt inn på både næringsinntak og sosialt samvær (16-18).

I 1995 ble det i retningslinjer 
for kosthold i helseinstitusjoner fokusert mer på måltidenes organisering enn tidligere, primært for å avhjelpe problemet med underernæring (19). I kvalitetsforskriften for pleieog omsorgstjenestene fra 1997 skulle måltidene i større grad tilpasses den enkelte gjennom et variert og helsefremmende kosthold. Større fleksibilitet skulle utøves i valg av tid og sted for måltidene, der de sosiale sidene ble særlig vektlagt (20). I høstens stortingsmelding blir det påpekt at sykehjemmene har vanskelig for å oppfylle alle måltidets funksjoner, deriblant det sosiale fellesskapet. En rapport vedrørende klinisk ernæring skal i nær fremtid ferdigstilles, der retningslinjene fra 1995 skal revideres og gjøres tjenlige som kvalitetsverktøy, også med tanke på måltidene (21).

Disse signalene aktualiserer artikkelens problemstilling. Til forskjell fra de ovenfor refererte studiene fokuserer denne studien på måltidsfellesskapet som fenomen alene i lys av opplevelsene til en liten gruppe pasienter ved ett sykehjem. Ved å presentere funnene i lys av andre studier og forskningslitteratur (1), ønsker jeg å belyse og drøfte følgende problemstilling i denne artikkelen: Hvordan opplever eldre pasienter det sosiale fellesskapet rundt måltider i sykehjem?

\section{TEORETISK}

\section{REFERANSERAMME}

Sosiologisk sett knyttes måltidene opp mot fellesskapet rundt maten, bordet og samtalen. Simmel karakteriserer det å spise som en fysiologisk primitiv individuell handling, som gjennom måltidsfellesskapet og dets regler fremstår mer estetisk gjennom samværet (22). Mat er ikke bare livsviktig, men er også et livsnødvendig sosialt bindemiddel (23). Mäkelä kategoriserer fenomenet i en strukturell eller materiell-teknisk dimensjon, samt i en sosial og i en formell dimensjon. Den sosiale dimensjonen kommer til uttrykk gjennom de ulike forordningene for hvordan man sitter, hvordan det serveres og spises under måltidet. A spise blir slik en sosial hendelse i en ritualisert interaksjon, som organiserer og sier noe om sosiale fellesskap i sosiale grupper og samfunn. Den formelle dimensjonen vil med ulike typer av regler virke inn på den strukturelle og sosiale organiseringen av måltidet gjennom graden av formalitet $\mathrm{i}$ ulike matsituasjoner (24).

Måltidene vil være mer eller mindre formelle og intime, der man gjennom kommunikasjon markerer nærhet og distanse (24). Måltidene gjør oss sosiale, der mennesker uten felles interesse kan finne sammen (22). Har man ikke interesse for dette fellesskapet, mener Thorsen at måltidet lett reduseres til et rent matinntak (23). Simmel eksemplifiserer dette med relasjonene rundt et pensjonatbord, der man kun møtes for å spise uten interesse for de andre rundt bordet. Men spiser man alene, deler man likevel måltidet som en kulturell idé. Et skikkelig måltid liknes i mange sammenhenger med sosiale hendelser i familien (22). Et godt måltid henger ikke bare sammen med det kjente og vante, både sosiale og psykologiske faktorer spiller inn. Til mat og måltider knyttes minner som kan støtte opp om den enkeltes identitet og integritet (25). Thorsen hevder at de sterkeste minnene om livet er knyttet til mat, der smaksopplevelser, dufter og ulike stemninger kan fremkalles (23).

\section{METODE}

Siden informantenes opplevelser ble fokusert i studien, ble kvalitativt forskningsintervju valgt som metode. I slike personlige intervjuer retter forskeren oppmerksomheten mot informanten, der intervjueren er styrt av intervjuguiden og det informanten forteller. Gjennom samtalen fokuseres det som eksisterer naturlig for den enkelte, der formålet er å fange informantens perspektiv på egne opplevelser relatert til samtalens tema (26). Intervjuguiden skal inneholde aktuelle tema i den rekkefølge de er tenkt brukt under samtalen. I halvstrukturerte intervjuer kan guiden inneholde forslag til spørsmål, som skal gi retning og dynamikk til samtalen (27). I denne studien ble intervjuguiden utformet $\mathrm{i}$ tråd med teoretisk referanseramme og tidligere studier etter mønster av Hougs intervjuguide (12). Spørsmålene ble knyttet opp mot fem ulike tema: fysisk miljø, måltidsorganisering, psykososialt fellesskap, omsorg og respekt, samt egen funksjonsevne og helse. Intervjuguiden ble ikke fulgt slavisk under intervjuene, men ble anvendt som kognitiv ramme, og sett raskt over mot slutten av hvert intervju (26).

Intervjuene fant sted på pasientenes enerom med varighet fra en halv til halvannen time. $\AA$ intervjue eldre pasienter som sjelden sitter i lengre samtaler, og langt mindre i nærheten av en båndopptaker, gav ulike utfordringer underveis. Mange hadde større behov for en uformell samtale om egen familie og sitt levde liv, enn å fortelle om måltidets karakter i sykehjemmet. Utfordringen ble å knytte tråden i samtalen til studiens tema. De ble fort slitne, og seks av disse syv ble intervjuet to 
ganger. Samtlige intervjuer ble tatt opp på bånd og fortløpende transkribert. Siden det viste seg vanskelig å holde tråden under intervjuene, ble irrelevante utsagn ikke transkribert. Utsagn med usikker relevans ble transkribert, da såkalt utenomsnakk også kan gi viktige data (26). Etter endt transkripsjon hørte jeg gjennom lydbåndene på nytt, og sentrale utsagn ble markert. Hvert av intervjuene ble vurdert i forhold til intervjuguiden. Spørsmål som manglet svar, ble isolert. Disse gav retning til oppfølgingsintervjuene, som også ble transkribert fortløpende.

Analysen pågår under hele intervjuprosessen. Under intervjuet er det informantenes utsagn og selvforståelse som fokuseres. Senere, i dialog med utskriftene, er utfordringen å være tro mot det som ligger der av dypere mening. Siden utskriftene da alene skal legge føringen for analysen (26), ble intervjuguiden lagt bort etter avsluttet oppfølgingsintervju. Samtlige utskrifter ble i sin helhet lest flere ganger, slik Kvale skisserer. Ved å markere sentrale utsagn og gruppere disse etter tekstens tilbakevendende tema på tvers av intervjuene, ble teksten meningsfortettet. Meningsenhetene ble lest flere ganger før endelig gruppering. Disse ble analysert i tre ulike kontekster; selvforståelse, allmenn forståelse og teoretisk forståelse. Tolkningen av utsagnenes innhold foregår da i en annen forståelsesramme enn informantens (27). I denne artikkelen kommer pasientens selvforståelse til uttrykk i siterte utsagn og sammenfatninger under presentasjonen av funnene. I diskusjonsdelen blir disse funnene relatert til allmenn og teoretisk forståelse som her representerer andre studier og teoretisk referanseramme.

Denne analysen bygger på relativt få og personavhengige utsagn. Skal analysen fremstå troverdig, må det argumenteres for fremstillingen på systematisk og rasjonelt vis. Gjennom hele forskningsprosessen ligger metodiske, empiriske og teoretiske føringer (26). Problemstilling og intervjuguide er profilert ved hjelp av teori og tidligere studier. Under intervjuene var jeg åpen for hva pasientene fortalte, og var bevisst egen forforståelse. Transkripsjon og analyse fordrer systematikk og trofasthet mot føringene i utsagnene som følges videre i diskusjonen, der de sammenholdes med annen kunnskap og viten.

\section{UTVALGSKRITERIER OG ETISKE OVERVEIELSER}

Lederen av helse- og sosialtjenesten i en kommune ble kontaktet og informert om innholdet i studien. Vedkommende ba avdelingssykepleierne ved ett sykehjem om å velge aktuelle informanter etter gitte inklusjonskriterier. Følgende kriterier lå til grunn: informanten må være orientert for tid, sted og situasjon; må kunne uttrykke seg greit muntlig og forstå det som blir formidlet; gi informert samtykke; være over 70 år; kunne innta mat og drikke med eller uten hjelp; og hatt permanent opphold ved sykehjemmet i minimum en måned. Det krevdes ikke deltakelse på alle fellesmåltider under prosjektperioden, men at de hadde egne pasienterfaringer fra dette måltidsfellesskapet (1).

De som falt innenfor kriteriene, ble forespurt og informert skriftlig og muntlig om studien av avdelingssykepleier. Samtlige signerte skjema for informert samtykke. De bekreftet $\mathrm{da}$ at dette var frivillig fra deres side, og at de var informert om hva det innebar å være med i studien (27). Regional komité for medisinsk forskningsetikk, Region Vest, hadde på forhånd gitt klarsignal til prosjektet, og Norsk samfunnsvitenskapelig datatjeneste hadde etter melding til Datatilsynet gitt konsesjonsfritak for personregister. Registrering, oppbevaring og bruk av data under prosjektperioden ble gjort etter gjeldende regler, der forskningsetiske retningslinjer gitt i Helsinki-deklarasjonen ble fulgt. Ved blant annet ikke å presentere detaljerte opplysninger om institusjon eller informanter, skal anonymiteten ivaretas. Sykehjemmet er i norsk målestokk heller lite, og muligheten for å kjenne igjen personene bak fortellingene lokalt ville ha vært til stede. Her finnes ingen fremmedkulturelle pasienter. Begge kjønn kunne delta på lik linje, men kun en av de intervjuede var mann. Kjønnsrelaterte forskjeller ble ikke fokusert i studien, til det var utvalget for lite. Funnene publiseres derfor kjønnsnøytralt, der samtlige informanter omtales som kvinner. De enkelte utsagnene blir ikke personifisert.

\section{PRESENTASJON AV FUNN}

Studien ble utført ved et sykehjem i et lite lokalsamfunn i Norge. Her er to avdelinger med tilbud om opphold av både lengre og kortere varighet, og med egne skjermede lokaler for mennesker med demenstilstander. Maten ble vanligvis tilberedt ved eget kjøkken og kjørt til avdelingene i store vogner. Spisestuene var innredet med anretningskjøkken lokalisert 
nært opp til fire-fem avlange spisebord av ulik lengde med plass til flere rundt hvert bord. Samtlige informanter tok seg frem på egen hånd. De fleste ved hjelp av rullator og en ved hjelp av rullestol. En av disse inntok måltidene alene på eget rom etter eget ønske, mens de resterende fordelte seg på to ulike spisestuer. I det følgende presenteres deler av studiens funn som kunne relateres til artikkelens problemstilling sammen med noen sentrale pasientutsagn (1).

\section{Å bli servert \\ Måltidene var tilrettelagt slik at de fleste langt på vei var selvhjulpne, selv med ulike syk- domsbilder og reduserte evner til å hjelpe seg selv. De uttrykte mangel på krefter til å enga- sjere seg i måltidet utover det å spise maten. Få hadde tanker om hvordan serveringen faktisk foregikk. Samtlige var fornøyde med ferdigporsjonert mat ser- vert på tallerken: "Jeg liker å streve med tingene selv, men nå er jeg så dårlig, at jeg liker å få det ferdig. Jeg kan ikke noe annet heller.»}

\section{Bordets beskaffenhet}

Rommenes og bordenes beskaffenhet oppfattes som greie nok. En uttrykte at det viktigste var stillhet og fred under måltidet. Dekketøyet var de ikke så opptatt av, men mer av at det var fint dekket på, at orden og hygiene ble ivaretatt: "Under ettermiddagskaffen sitter vi $i$ stolene vare ved noen småbord med duker på. De dekker pent på. Ja, det har voert stelt til med blomster på bordene, og det liker jeg.»

Flere satte pris på blomster til oppmuntring og inspirasjon for samtale, og til fremkalling av minner om egen have og eget hjem. Noen fremhevet bildene som prydet veggene, der motiv hentet fra hjemtraktene var med å bringe frem minner. Vevde tepper ble også trukket frem som gode å se på, og som kilde for samtale. Likevel var det viktigst å spise maten, fremfor å se på hvordan det forholdt seg rundt en.

\section{Bordfellesskapet}

«Det er fint å sitte der inne, helt supert! Det ser ut til at noen setter pris på à komme seg ut igjen fort, men jeg for min del sitter der gjerne. Men en kan $i k k e$ ta seg all verden av tid heller, for personalet skal jo giøre jobben sin. En kan ikke bruke dette som oppholdsrom slik.»

De fleste uttrykte at de trivdes i selskap med de andre pasientene rundt bordet. De ville heller det enn å sitte på eget rom og spise alene. Noen fremhevet spesielt tryggheten det representerte. De fleste mente at redusert hørsel kunne gjøre mange samtaler vanskelige, der stillheten ofte dominerte. Flere fortalte om givende og humørfylte samtaler, som gav gode følelser etter endt måltid. For noen var måltidene noe å se frem til. Damen som tilbrakte store deler av dagen på eget rom, mente hun ikke var så avhengig av selskap. Under måltidene derimot kunne hun snakke mye med damen ved siden av seg. Flere var der ikke å snakke med.

En annen mente hun opplevde et ekstra samhold, men savnet rammen rundt måltidet som opplesningen av en bordbønn ville gitt. Måltidene hadde for henne en rolig atmosfære. Innimellom hadde hun noen ved siden som gjorde det utrivelig, men det forsøkte hun å ta som det kom. Den av de syv som inn- tok alle måltidene på eget rom, opplevde fellesskapet ubehagelig. Da hun var ny i avdelingen, hadde hun sittet sammen med de andre under måltidet. Det ble for tungt å se unge som gamle $i$ all deres elendighet, samtidig som hun selv skulle håndtere egne begrensninger: "Jeg tvinger meg ikke til noe jeg ikke greier. Det gikk så innpå meg! ... Ingen vet hvordan dette kjennes, for de er kommet så langt selv at de må ha hjelp og slik. ... Det betyr mye at jeg fär sitte alene à spise. Ja, det liker jeg best.»

En annen sa rett ut at det var for mange «tutlete» der. Hun mente det var lite samhold rundt måltidet: «Når jeg kommer inn til bordet, så sier jeg ikke noe til noen. Jeg sitter der og fär maten min. Men hun ved siden av meg, hun liker ikke at jeg kommer inn på henne på en måte... Jeg sitter rett og slett for meg selv. Jeg kan ikke akkurat rope overalt heller!»

Denne damen var veldig tunghørt. Hun hadde andre å snakke med utenom måltidene, men kjente seg lett isolert ved matbordet. En annen med redusert hørsel opplevde det ikke slik. Hun hadde to samtalepartnere ved bordet, og syntes det var tryggere og kjekkere å sitte sammen med noen når hun spiste. Hun hørte ikke alltid hva som ble sagt, men ville de hun skulle høre, tok de hensyn til det.

\section{Forholdet til personalet}

Pasientene viste stor forståelse for personalets travelhet. De fleste trakk frem at travelheten hindret personalet $\mathrm{i}$ å sette seg ned under måltidene. Noen mente at de knapt vekslet ord med dem da, og noen mente sågar at dette var helt i orden: "Personalet går rundt her under 
måltidet. Og innimellom prater de nå litt med oss. ... Det er greit nok at de gar der slik, og ikke setter seg ned under måltidet.»

Ingen ytret direkte ønske om at de burde sette seg ned ved bordet, men flere opplevde det positivt når de gjorde det. Ettermiddagskaffen ble av flere fremhevet som spesiell i så måte. Da satt de ved små runde bord som gav mer rom for samtale. Personalet var mer selskapelige enn ellers, og flere fikk noen å samtale med. A ha flere mentalt klare til stede var et uttalt savn for noen: "Det er nok ikke mye tid for dem til à slappe av på den måten. Men det kunne kanskje ha voert en fordel at det var noen som var klare. När de kjenner stedet og bygden her, de som lever og har levd her, så kan det vore et kontaktpunkt. ... Gammelt folk har lett for å prate mye, og far de ikke det, øker ensombeten, og det knekker dem til slutt.»

\section{DISKUSJON}

Disse opplevelsene skriver seg fra syv pasienter i ett sykehjem, og kan slik ikke generaliseres til å være allmenngyldige. Hvert av temaene er imidlertid sammenfallende med Mäkeläs sosiale dimensjon (24). Pasientene har fortalt om ulike opplevelser knyttet til måltidene, som generelt bør være viktige å ta hensyn til. Man kan ikke se bort fra at de kan ha uttalt seg med forsiktighet for ikke å støte noen.

\section{Daglige sosiale}

\section{samlings-punkter}

De eldre forteller at de setter pris på å sitte sammen med andre pasienter under måltidene. Det foretrekkes fremfor å sitte alene på rommet og kjenne på ensomheten. Flere av pasien- tene trekker frem et fellesskap med positiv atmosfære. Den sosiale dimensjonen fremheves av Simmel som noe av det sentrale ved måltidet. Man søker samværet primært for å være sosial, ha det hyggelig sammen og vise hverandre respekt (22). Slike samværsformer er funnet i sykehus, der måltidene ble et avbrekk i seg selv (28). For sykehjemspasientene representerer måltidene også noe å se frem til i kontrast til hvordan de ellers ventende tilbringer dagene. Måltidene kan gi dem samtalepartnere uten forpliktelser utover øyeblikkets samtale som en kjærkommen avveksling i hverdagen.

Et skikkelig måltid lignes ofte med måltidet i familiære sammenhenger $(22,23)$. Måltidet i sykehjem har ingen privat karakter som hjemme. De vil gjerne slippe å sitte alene, men uten frihet til å velge hvem de inntar måltidet sammen med, kan fellesskapet få et tvungent preg (29). Det tvungne blir gjerne underordnet for dem som har innfunnet seg med situasjonen, og «prøver å gjøre det beste utav det» som noen uttrykte det. Det ubehagelige kan ligge i å møte opp bare for å spise, men ikke for å delta i samværet rundt bordet (22). En av de intervjuede valgte å spise på eget rom. For henne ble pasientfellesskapet, eller mangelen på dette, ødeleggende for eget velvære under måltidet. Dersom fellesskapet ikke representerer den trygghet, hygge, forståelse eller tillit som en forventer, oppsøkes det heller ikke. Hauge hevder at i institusjoner for mennesker med store omsorgsbehov, vil mange ikke ha ressurser til å delta i slike krevende fellesskap (30). Pasientene ved sykehjemmet gir uttrykk for dette ved å vise til mangelen på krefter til å engasjere seg i noe utover det mest nødvendige. Mange kjenner på en skrantende helse med lite overskudd til mer enn å klare seg selv under måltidet, forflytte seg mellom rommene og fremstå mest mulig selvhjulpen.

Ulike studier viser at pasienter i varierende grad selv avgjør hvor de skal spise $(10,11,13$, 14). I denne studien lot det til at de fleste søkte samværet rundt matbordet. Få spiste alene på eget rom. Noe de formidlet var opp til dem selv. Karniala hevder at det ikke trenger være behovene eller ønskene pasientene har som styrer organiseringen av måltidene (7). I mange sykehjem kan det være et uttalt ønske fra personalets side å samle pasientene til et felles måltid. Begrunnelsen kan ligge i en effektiv avvikling av måltidene, eller nettopp i et ønske om måltidene som sosiale samlingspunkter $(22,24)$.

Ved dette sykehjemmet representerer måltidene daglige, tilbakevendende og regulerte treffpunkter $(28,29)$. Måltidene oppfattes som sosialt samlende, og for noen som berikende. De intervjuede formidler at de kjenner på samholdet seg imellom under måltidene. De er gjerne de mest ressurssterke ved sykehjemmet, og kan i større grad enn mange av de andre pasientene trekke veksler på fellesskapet. På tross av dette finnes der en viss innebygd skjørhet, slik Hauge påpeker i sin studie. Pasientene makter ikke å være aktive i hverandres selskap, når bordet deles med mennesker som ikke angår dem. Hennes funn indikerer at fellesskapet først blir meningsfullt for pasientene når personalet er til stede (30). Selv om pasientene sjelden søkte hverandres selskap utenom 
måltidene, vektla flere samværet med de andre som positivt.

\section{Få samtalepartnere}

Under måltidet utfordres nærhet og distanse gjennom hvordan vi kommuniserer med hverandre (24). Reduserte kommunikasjonsevner kompliserer måltidsfellesskapet ved sykehjemmet. Pasientene forklarer mangelen på samtalepartnere hovedsaklig med redusert hørsel. Få fokuserer på mentale forandringer hos seg selv eller andre. De forteller om både samtaler og stillhet under måltidene. Noen hadde opplevd humørfylte samtaler som gav kvalitet til samværet, og som var medvirkende til at de sammen kjente seg vel. Hauge beskriver samtalene mellom pasientene i dagligstuen som svært personalavhengige. Siden mange av disse ofte har reduserte mentale ressurser, mener hun det oppstår en kommunikativ kollaps (30). I denne studien gav noen av de intervjuede uttrykk for at de selv kunne ta initiativ til samtaler som gav samværet kvalitet. Det vitner om trygghet og interesse for å delta i fellesskapet fra deres side. Reduserte kommunikasjonsforutsetninger og lite overskudd til samtale, var likevel en reell utfordring for samtlige.

Selv om Simmel ser måltidet som en anledning for ukjente til å bli kjent med hverandre (22), er det ikke for enhver gitt å finne sammen i sykehjem. For når mentale forandringer og reduserte sanser gjør det vanskelig både å se og huske den andre, vil fellesskapet lett kunne bli skadelidende (2). Det stiller krav til personalets tilstedeværelse, og til hvordan og med hvem pasientene sitter under måltidet. Bordplasseringen legger føringer for både samtaler og felles- skap ved bordene (15). Siden dette sykehjemmet er lokalisert $i$ et lite lokalsamfunn, kjenner mange av pasientene hverandre fra tidligere. Disse finner gjerne lettere sammen ved bordet enn andre. Har man ikke interesse for dem som sitter nært opptil, vil det vanskeliggjøre enhver relasjon $(2,30)$. Pasientene sier de som oftest samtaler med dem som sitter nærmest. Store bord kan slik være til hinder, mens små bord kan fremme kommunikasjon (15). Pasientene trekker frem kaffemåltidet med sine småbord som noe eget. Gjennom bordets beskaffenhet kommer de nærmere hverandre. Duker og blomster gjør omgivelsene triveligere. Personalet fremstår mindre travle, og gir rom for samtale ved sin tilstedeværelse under måltidet, slik også Hauge beskriver i sin analyse (30).

For å kunne dele noe sammen med andre må det skapes meningsfulle måter å være sammen på. Det krever at man forholder seg til hverandre som enkeltindivider. Ved å gjøre den ene synlig for den andre, knyttes og opprettholdes ulike relasjoner $(2,25)$, og slik fremmes fellesskapet gjennom samtalen. Personalets kunnskaper om pasientene, deres historie og nærmiljø vil kunne fremme pasient- og personalinitiert samtale, og følgelig matens og samtalens nytelse. Måltidene representerer noe felles gjennom maten og menneskene, der den sosiale rammen skapes av dem som er til stede. Heri ligger utfordringen til personalet; å fremme pasientenes velvære og egeninteresse ved å bygge på den enkeltes iboende krefter, kunnskaper og vilje (5).

Personalets tilstedeværelse Som ved flere andre sykehjem er måltidene også her preget av et personale i travelhet $(8-11,13$, 14, 29, 30). Pasientene viser stor forståelse, men etterlyser indirekte personalets selskapelighet. Kaffemåltidet fremheves som noe eget, delvis grunnet personalets tilstedeværelse. Studier viser også at pasienter setter pris på personalets samvær under måltidene både som samtalepartnere og som en trygghetsfaktor. Når mangelen på samtalepartnere viser seg å være et problem for mange pasienter i sykehjem $(9,11,30)$, har personalet en stor utfordring i å kompensere for dette. De kan på ulike måter være behjelpelige med å sette samtaler i gang ved å dvele rundt tidligere hendelser, minner og dagens begivenheter sammen med pasientene (25). Noen av pasientene fremhevet spesielt slike øyeblikk med personalet. Til forskjell fra mange av pasientene er personalet delaktige i samfunnslivet utenfor sykehjemmet gjennom eget arbeid og sosialt liv. De kan dermed gjennom samtaler med pasientene formidle biter av livet utenfor institusjonen.

\section{KONKLUSJON}

Artikkelen har fått frem ulike sider ved sosiale fellesskap rundt måltider i sykehjem i lys av syv pasienters opplevelser. Måltidene er viktige samlingspunkt i en monoton hverdag. Pasientene får en kjærkommen aktivitet å gå opp i, og gjerne en samtalepartner, men reduserte kommunikasjonsevner kompliserer det hele. Noen kan likevel ha glede av å være til stede under et måltid uten selv å delta i samtalen. Det sosiale fellesskapet kan ta ulike former i kraft av hva pasientene selv evner og ønsker å bidra med. Det er ikke gitt for alle å finne glede i ethvert felles måltid. Mange har mer enn 
nok med maten, men den sosiale dimensjonen er like fullt sentral, selv om det sosiale fellesskapet fremstår som krevende. Ved å fokusere på disse utfordringene knyttet til måltidene i sykehjem, kan personalet utnytte måltidene til å styrke dette fellesskapet med de forutsetninger som ligger der. Personalet kan gjøre samværet

\section{REFERANSER:}

1. Melheim BG. Å gå til duk og dekka bord - Eldre og matkultur i sjukeheim. Bergen: Institutt for samfunnsmedisinske fag; 2004

2. Brunstad PO. Måltidet - menneskets «ødested». I: Brunstad PO. Seierens melankoli - et kulturanalytisk essay. Oslo: Gyldendal Akademisk, 2003.

3. Nightingale F. Notes on nursing: What it is, and what it is not. Boston: William Carter 5thWater Street; 1860.

4. Nissen R. Lærebog i sygepleie. Oslo: Gyldendal Akademisk; 2000.

5. Harmer B, Henderson V. Textbook of the principles and practice of nursing. New York: The Macmillan Company; 1939.

6. Kirkevold M. Sykepleieteorier - analyse og evaluering. Oslo: Ad Notam Gyldendal; 1998.

7. Karniala A. Spisning som et spejlbilde af sygeplejens fokus. Klin Sygepl 1993; $7(5): 2-8$.

8. Sørensen BA. Sykehjem - velferdsstatens bakgård? Noen resultater fra en undersøkelse blant beboere, pårørende og ansatte ved et sykehjem i Oslo. Oslo: Arbeidsforskningsinstituttet. AFI-notat 10/95; 1995

9. Pedersen B, Jensen Tø. Vi skal ikke vente oss noe ekstra heller, når vi er så gamle. Brukererfaringer fra bergenske sykehjem. Bergen: SEFOS-notat 110; 1995.

10. Sletvold O, Solbu H, Hofstad T. Kvalitet i sykehjem. Bergen: Nasjonalt geriatriprogram 1994-99. Rapport nr.2; 1999. rundt maten mer meningsfullt for pasientene ved selv å delta under måltidene som samtalepartnere. Slik kan de kompensere der pasientene selv ikke strekker til. Ved å se måltidene som en mulighet for sosialt samvær og hygge, og ikke som et matinntak alene, kan velvære og fellesskap skapes til tross for utfordringene.
Artikkelen problematiserer ikke hvordan pasientene opplever å være hjelpeavhengige i slike relasjoner, og hvordan de opplever å bli ivaretatt av personalet. $r$ ønskelig å komme tilbake til dette forholdet basert på funn fra min studie i en senere artikkel (1).

11. Gjerberg E. Kvalitet i sykehjem? En analyse av virksomheten slik avdelingssykepleierne ser det. Oslo: Statens institutt for Folkehelse. Arbeidsrapport nr. 2; 1995.

12. Houg T. Takk bare bra ...? Flytteprosessen og hverdagen på sykehjem. Oslo: FAFO-rapport 2000; 1996.

13. Egeland L, Gjerberg E. God kvalitet på sykehjem? Hva mener pårørende? En studie blant pårørende ved 28 sykehjem i Norge. Oslo: Statens institutt for Folkehelse. Utredningsrapport nr. U1; 1996

14. Slagsvold B. Velferd og levekår for sterkt hjelpeavhengige eldre tjenestebrukere. En datadokumentasjon med kommentarer. Oslo: Norsk institutt for oppvekst og aldring; 2000.

15. Elvbakken KT. Mat, alderdom og eldreomsorg. Oslo: Kommuneforlaget; 1993.

16. Steen B. Måltidens betydelse inom geriatriken. I Telegin ML, ed. Måltiden och måltidsordningen. Uppsala: Forskningsrådsnämden, 1991.

17. Elmståhl S, Blabobil V, Fex G, Küller $\mathrm{R}$, Steen B. Hospital nutrition in geriatric long-term care medicine. Effects of a changed meal environment. Compr Gerontol A 1987; 1 (1): 29-33.

18. Thomasson J. Trevligare måltider nyckeln til förbättringar. Vårdfacket 1993; 17 (3):18-19.

19. Statens ernæringsråd. Retningslinjer for kostholdet i helseinstitusjoner. Oslo: Universitetsforlaget; 1995.
20. Sosial- og helsedepartementet. Rundskriv om kvalitet i pleie-og omsorgstjenestene. Oslo; 1997.

21. Helse- og omsorgsdepartementet. Stortingsmelding $\mathrm{nr} 25$ (2005-2006) http://odin.dep.no/hod/norsk/dok/regpubl/stmeld/bn.html Besøkt 13.oktober 2006

22. Simmel G. Måltidets sosiologi. Sosiologi i dag 1993; 23 (1): 3-9

23. Thorsen K. Maten i livet - Matens psykologi i et livsløpsperspektiv. Oslo: Norsk Gerontologisk Institutt; 1993.

24. Mäkelä J. Defining a meal. I: Fürst EL, Prättälä R, Ekström M, Kjærnes U, eds. Palatable worlds. Sociocultural food studies. Oslo: Solum Forlag; 1991.

25. Heap K. Samtalen i eldreomsorgen - Kommunikasjon - minner - kriser sorg. Oslo: Kommuneforlaget; 2002.

26. Fog J. Med samtalen som udgangspunkt - Det kvalitative forskningsintervju. Oslo: Ad Notam Gyldendal; 1997.

27. Kvale S. Det kvalitative forskningsintervju. Oslo: Ad Notam Gyldendal; 1997.

28. Album D. Nære fremmede - pasientkulturen i sykehus. Oslo: TANO; 1996.

29. Røssland A. Behov for hjelp, mulighet til selvbestemmelse og tilfredshet med sykehjemmet. Bergen: Institutt for samfunnsmedisinske fag; 2001.

30. Hauge S. Jo mere vi er sammen, jo gladere vi blir? - ein feltmetodisk studie av sjukeheimen som heim. Oslo: Institutt for sykepleievitenskap og helsefag; 2004. 